\title{
PENGARUH SISTEM INFORMASI AKUNTANSI PERSEDIAAN TERHADAP PENGENDALIAN INTERNAL PERSEDIAAN PADA PT TRIJATI PRIMULA
}

\author{
${ }^{1}$ Dewi Selviani Y, ${ }^{2}$ Siti Aminah Siregar \\ Program Studi D4 Akuntansi Keuangan \\ Politeknik Pos Indonesia \\ dewiselviani@poltekpos.ac.id, sitiaminah9763@yahoo.com
}

\begin{abstract}
ABSTRAK
Informasi merupakan hal yang sangat penting bagi perusahaan dalam mengelola perusahaan, menjalankan operasional perusahaan dan sebagai alat mengambil sebuah keputusan. PT. Trijati Primula merupakan perusahaan yang ditunjuk resmi oleh PT. Chitose International Tbk sebagai distributor resmi produk Chitose. "Fenomena yang sering terjadi pada perusahaan distributor adalah hal yang tak terduga terjadi pada saat pengiriman seperti kecelakaan serta hujan deras yang mengakibatkan barang rusak. Oleh karena itu sebuah perusahaan distributor perlu pengendalian internal yang maksimal. Penelitian ini bertujuan untuk mengetahui pengaruh Sistem Informasi Akuntansi Persediaan Barang terhadap Pengendalian Internal Persediaan di PT Trijati Primula. Metode yang dipakai adalah metode kuantitatif dengan analisis asosiatif. Sistem informasi akuntansi persediaan memiliki hubungan yang kuat terhadap pengendalian internal persediaan dan memiliki pengaruh sebesar $88,9 \%$. Kesimpulannya adalah sistem informasi akuntansi persediaan berpengaruh signitifikan terhadap pengendalian internal petsediaan pada PT Trijati Primula.
\end{abstract}

Kata kunci: sistem informasi, persediaan, pengendalian

\begin{abstract}
Information is very important for companies in managing the company, running company operations and as a tool for making decisions. PT Trijati Primula is a company that is officially appointed by PT Chitose International Tbk as an official distributor of Chitose products. The phenomenon that often occurs in distributor companies is something unexpected happens during delivery, such as accidents and heavy rain which cause damaged goods. Therefore, a distributor company needs maximum internal control. This study aims to determine the effect of the inventory accounting information system on internal inventory control at PT. Trijati Primula. The method used is quantitative method with associative analysis. Inventory accounting information system has a strong relationship to internal inventory control and has an effect of $88,9 \%$. The conclusion is that the inventory accounting information system has a significant effect on internal control of supplies at PT. Trijati Primula.
\end{abstract}

Keywords: information system, inventory, internal control

\section{PENDAHULUAN}

\section{Latar Belakang}

Dalam sebuah perusahaan ataupun organisasi, salah satu sumber daya yang sangat diperlukan oleh manajemen untuk mengambil keputusan adalah informasi. Sistem yang dapat mengolah data menjadi sistem informasi yang berharga ini akan menghasilkan informasi bagi pihak eksternal maupun internal perusahaan. Sistem tersebut disebut information processing system atau sistem informasi. Adapun tujuan dari sistem tersebut adalah untuk memberikan informasi dalam pengorganisasian, perencanaan, dan operasional suatu perusahaan serta dalam proses pengendalian pengambilan keputusan. Perusahaan harus mempunyai sistem informasi yang baik dan efektif untuk membantu manajemen mengambil keputusan demi tercapainya tujuan kemajuan perusahaan.

Kehilangan dan kerusakan barang dagang yang sering terjadi pada perusahaan distribusi merugikan perusahaan karena secara otomatis mengurangi jumlah persediaan barang dagang perusahaan yang pada akhirnya berdampak kepada pengurangan profit 
yang seharusnya diterima perusahaan. Selain itu kehilangan dan kerusakan barang dagang juga akan menyebabkan hilangnya kepercayaan konsumen dan pihak lainnya yang berkepentingan terhadap perusahaan.

Fenomena yang sering terjadi pada perusahaan distributor adalah ketika pengiriman barang kepada konsumen terjadi kecelakaan, mobil pengangkut barang terbalik, supir mengantuk, dan musim hujan yang dapat mengakibatkan kerusakan barang bahkan kehilangan barang pesanan konsumen dan juga kesalahan pencatatan. Hal tersebut yang sering membuat konsumen kecewa karena barang pesanan yang tidak kunjung sampai. Adapun hal yang sering perusahan lakukan untuk mengendalikan hal tersebut adalah membuat asuransi perjalanan pengiriman barang yang mengakibatkan pesanan konsumen memerlukan waktu lebih lama lagi untuk memperoleh pesanannya karena perusahaan harus memproduksi kembali atau tidak adanya persediaan barang tersedia. Hal tersebut sering membuat konsumen kecewa sehingga tidak tertutup kemungkinan konsumen tersebut akan berhenti berlangganan pada perusahaan.

Penelitian yang berkaitan dengan sistem informasi akuntansi persediaan dan pengendalian internal persediaan adalah penelitian Mugiarti (2016) yang berjudul Pengaruh Sistem Informasi Akuntansi Persediaan terhadap Pengendalian Internal Persediaan Barang pada Toko Besi dan Bangunan Serba Guna di Ajibarang. Hasil penelitian ini menunjukkan bahwa sistem informasi akuntansi persediaan barang berpengaruh terhadap pengendalian internal persediaan barang pada toko besi dan bangunan serbaguna di Ajibarang sebesar 56,30\%.

Sedangkan penelitian yang dilakukan oleh Djuhara (2014) yang berjudul Pengaruh Sistem Informasi Akuntansi Persediaan Barang terhadap Pengendalian Internal Persediaan Barang pada CV. Tri Multi Manunggal Bandung. Hasil penelitian tersebut menyatakan bahwa Sistem informasi akuntansi persediaan barang dapat dikatakan berpengaruh terhadap pengendalian internal persediaan barang sebesar $75,70 \%$. Adapun penelitian yang lain adalah penelitian dari Meita Sekar Sari (2019) yang berjudul Pengaruh Pengendalian Internal Persediaan Dan Kualitas Sistem Informasi Akuntansi Terhadap Pencegahan Kecurangan (Fraud) Persediaan Pada PT. Indofarma Global Medica Bandar Lampung yang menunjukkan bahwa pengendalian internal persediaan dan kualitas sistem informasi akuntansi berpengaruh positif dan signifikan secara simultan terhadap pencegahan fraud (kecurangan), pengendalian internal persediaan berpengaruh positif dan signifikan terhadap pencegahan fraud (kecurangan) dan kualitas sistem informasi akuntansi berpengaruh negative terhadap pencegahan fraud (kecurangan).

Berdasarkan uraian di atas penulis tertarik untuk mengambil variabel yang akan dibahas dalam penelitian yaitu sistem informasi akuntansi persediaan dan pengendalian internal persediaan. Sistem informasi akuntansi persediaan menjadi variabel independen atau variabel yang mempengaruhi, sedangkan variabel dependen adalah pengendalian internal persediaan yang ada pada PT. Trijati Primula Bandung.

\section{Identifikasi Masalah}

Adapun identifikasi masalah dalam penelitian ini adalah :

1. Bagaimana sistem informasi akuntansi persediaan pada PT Trijati Primula?

2. Bagaimana pengendalian internal persediaan pada PT Trijati Primula?

3. Bagaimana pengaruh sistem informasi akuntansi persediaan terhadap pengendalian internal persediaan barang pada PT Trijati Primula?

\section{KAJIAN PUSTAKA \\ Pengertian Sistem}

Sistem adalah suatu jaringan prosedur yang dibuat menurut pola yang terpadu untuk melakukan kegiatan pokok perusahaan. Suatu sistem pada dasarnya adalah 
sekelompok unsur yang erat berhubungan satu dengan yang lainnya, yang berfungsi bersama-sama untuk mencapai tujuan tertentu (Mulyadi, 2016)

\section{Pengertian Informasi}

Informasi adalah data yang sudah diolah sehingga berguna untuk pembuatan keputusan. Data adalah representasi suatu objek. Data yang akurat, bila diproses akan menghasilkan informasi yang juga akurat. Informasi akurat sangat berguna untuk membuat keputusan, baik manajemen maupun orang lain. Data yang belum diolah belum dapat digunakan untuk pembuatan keputusan. Misalnya seorang mahasiswa diwakili oleh nomor mahasiswa, maka nomor mahasiswa ini adalah data (Winarno 2006).

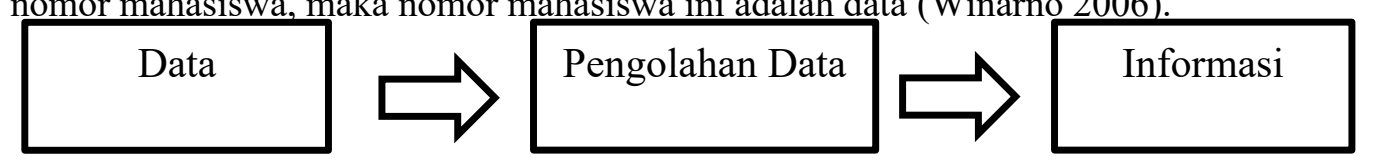

\section{Pengertian Akuntansi}

Akuntansi adalah kegiatan jasa. Fungsi akuntansi adalah menyediakan informasi kuantitatif tentang unit-unit usaha ekonomi, terutama yang bersifat keuangan, yang diperkirakan berguna dalam pengambilan-pengambilan keputusan ekonomi. Akuntansi merupakan aktivitas jasa, suatu disiplin ilmu/analisis dan sebagai suatu sistem informasi. Sebagai aktivitas jasa, akuntansi memberikan kepada pihak-pihak yang berkepentingan, informasi kuantitatif membantu mereka yang mengambil pelepasan dan penggunaan sumberdaya di dalam kesatuan bisnis dan juga bukan bisnis (Sigit Hermawan 2019).

\section{Pengertian Persediaan}

Persediaan merupakan salah satu aktiva lancar yang harus dikelola dengan baik, utamanya untuk perusahaan-perusahaan yang memiliki persediaan barang dagang. Persediaan ini akan dapat menentukan harga perolehan persediaan dan nilai persediaan yang akan disajikan di neraca. Persediaan digunakan untuk mengindikasikan barang dagang yang disimpan untuk kemudian dijual dalam operasi normal perusahaan, dan bahan yang terdapat dalam proses produksi atau yang disimpan untuk tujuan itu (Sigit Hermawan 2019).

\section{Pengertian Sistem Informasi Akuntansi Persediaan}

Sistem informasi akuntansi persediaan adalah suatu sistem yang mengumpulkan, mencatat, menyimpan, dan mengolah data untuk menghasilkan informasi bagi pengambil keputusan. Suatu sistem yang yang mengorganisir catatan persediaan yang dapat memberi tahu manajer apabila jenis barang tertentu memerlukan penambahan (B. Rommy 2016).

\section{Komponen Sistem Informasi Akuntansi}

Adapun komponen sistem informasi akuntansi terdiri dari:

1. Basis data, baik basis data internal (berada dibawah kendali perusahaan sepenuhnya) dan basis data eksternal (tidak dapat dikendalikan oleh perusahan).

2. Perangkat keras komputer dan berbagai perangkat pendukungnya, yang semuanya berfungsi untuk mencatat semua data, mengolah data, dan menyajikan informasi, baik secara hardcopy (tercetak) maupun softcopy (tidak tercetak).

3. Perangkat lunak komputer, yang berfungsi untuk menjalankan komputer beserta perangkat pendukungnya.

4. Jaringan komunikasi, baik dengan kabel, gelombang radio, maupun saran lain, yang berfungsi untuk menghantarkan data dan informasi dari satu tempat ke tempat lain.

5. Dokumen dan laporam (baik bersifat hardcopy maupun softcopy), yaitu media untuk mencatat data atau menyajikan laporan.

6. Prosedur, atau kumpulan langkah-langkah baku untuk menangani suatu peristiwa (atau transaksi) yang setiap hari terjadi di dalam perusahaan. 
7. Pengendalian, yang berfungsi untuk menjamin agar setiap komponen sistem dapat berfungsi dengan baik. (Winarno 2006)

\section{Pengertian Pengendalian Internal Persediaan}

Pengendalian persediaan diperlukan guna menjaga kuantitas fisik persediaan yang ada tetap sebagai harta perusahaan. Pengendalian persediaan harus dimulai segera setelah persediaan diterima oleh perusahaan. Pengendalian dilakukan dengan cara mencocokkan semua dokumen yang berkaitan dengan pembelian persediaan. Laporan penerima harus dicocokkan dengan pesanan pembelian, dan faktur yang tertera yang dikirim oleh pemasok. Setelah semua dicocokkan berikutnya harus mencatat persediaan dan utang usaha dalam catatan akuntansi perusahaan. Pengendalian secara fisik terhadap persediaan juga harus dilakukan dengan menggunakan tenaga perusahaan. Persediaan harus dimasukkan kedalam gudang yang tidak semua karyawan memiliki akses untuk keluar masuk gudang. Pengeluaran harus dilakukan dengan control melalui permulir permintaan barang, yang harus mendapat otorisasi dari pihak yang berwenang (Sigit Hermawan 2019).

\section{Komponen- Komponen Pengendalian Internal}

Komponen-komponen pengendalian internal adalah sebagai berikut:

1. Lingkungan Pengendalian

Lingkungan pengendalian merupakan sarana dan prasarana yang ada di dalam organisasi atau perusahaan untuk menjalankan sistem pengendalian internal yang baik. Tanpa lingkungan yang baik, system pengendalian internal yang bagus pun tidak dapat dijalankan dengan baik. Beberapa yang mempengaruhi lingkungan pengendalian internal adalah komitmen manajemen terhadap integritas dan nilai-nilai etika, filosofi yang dianut oleh manajemen dan gaya operasional yang dipakai oleh manajemen, struktur organisasi, komite audit untuk dewan direksi, metode pembagian tugas dan tanggung jawab, kebijakan dan praktik yang menyangkut sumber daya manusia, dan pengaruh dari luar.

2. Kegiatan Pengendalian

Kegiatan pengawasan merupakan berbagai proses dan upaya yang dilakukaan oleh manajemen perusahaan untuk menegakkan pengawasan atau pengaendalian operasi perusahaan. COSO mengidentifikasi setidak-tidaknya ada lima hal yang dapat diterapkan oleh perusahaan antara lain pemberian otorasi atas transaksi dan kegiatan, pembagian dan tugas tanggung jawab perancangan dan penggunaan dokumen dan catatan yang baik, perlindungan yang cukup terhadap kekayaan dan catatan perusahaan, dan pemeriksaan independen terhadap kinerja perusahaan.

\section{Pemahaman Resiko}

Setiap perusahaan memiliki resiko yang melekat pada karakteristik bisnisnya. Sebagai contoh, perusahaan angkutan memiliki resiko mengalami kecelakaan dijalan, perusahaan perkapalan memiliki resiko kecelakaan di laut, perusahaan penerbangan memiliki resiko kecelakaan di udara, perusahaan perkebunan menghadapi resikko diserang hama, dan bank menghadapi resiko kehilangan uang (bisa dengan salah hitung, pencurian lewat transfer illegal, dan perampokan).

4. Informasi dan Komunikasi

Perancang sistem informasi perusahaan dan manajemen puncak harus mengetahui hal-hal antara lain bagaimana transaksi diawali, bagaimana data dicatat ke dalam formulir yang siap di garis input ke sistem computer atau langsung dikonfersi ke sistem computer, bagaimana file data dibaca, diorganisasi, dan diperbaharui isinya, bagaimana data diproses agar menjadi informasi dan informasi diproses lagi menjadi informasi yang lebih berguna bagi pembuat keputusan, bagaimana informasi yang baik dilaporkan, dan bagaimana transaksi berakhir. Oleh karena perancang sistem perlu menanamkan suatu fasilitas yang memungkinkan digunakannya jejak audit tersebut. 


\section{Pemantauan}

Pemantauan adalah kegiatan untuk mengikuti jalan sistem informasi akuntansi, sehingga apabila ada sesuatu berjalan tidak seperti yang diharapkan, dapat diambil tindakan segera. Sedikit saja penyimpangan dibiarkan, akan menjadi besar, dan penyimpangan besar akan mengakibatkan sistem terganggu atau tidak berfungsi. (Winarno 2006)

\section{METODE PENELITIAN}

Jenis Penelitian

Metode yang dipakai dalam penelitian ini adalah metode kuantitatif dengan analisis asosiatif. Penelitian kuantitatif adalah metode penelitian yang berlandaskan pada filsafat positivisme, digunakan untuk meneliti pada populasi atau sampel tertentu, dan pengumpulan datanya menggunakan instrumen penelitian, analisis datanya bersifat kuantitatif atau statistik, dengan tujuan untuk menguji hipotesis yang telah ditetapkan (Sugiono 2019).

\section{Operasional Variabel}

Penelitian ini terdiri dari variable independen da variable dependen, yaitu:

\section{Variabel Independen}

$$
\mathrm{X}=\text { Sistem Informasi Akuntansi Persediaan }
$$

\section{Variabel Dependen}

$\mathrm{Y}=$ Pengendalian Internal Persediaan

\section{Populasi Dan Sampel}

Populasi yang terdapat dalam penelitian ini adalah 34 orang karyawan PT Ttijati Primula. Adapun jumlah sampel adalah 25 karyawan. Dasar pemilihan sampel adalah karyawan yang memahami sistem pengendalian internal persediaan, mengerti sistem pengendalian internal yang ada pada perusahaan, serta karyawan yang menggunakan sistem pada perusahaan.

\section{Teknik Pengumpulan Data}

Penelitian ini menggunakan sumber data primer yang didapat melalui kuesioner. Adapun pertanyaan yang terdapat dalam kuisioner terdiri dari 14 pertanyaan untuk variabel $\mathrm{X}$ dan 14 pertanyaan untuk variabel $\mathrm{Y}$. Pertanyaan dari setiap variabel dibuat berdasarkan penelitian terdahulu dan studi pustaka yang telah dikumpulkan. Kuisioner ini dibagikan kepada 25 karyawan yang telah ditetapkan sebagai sampel.

\section{HASIL DAN PEMBAHASAN}

\section{Uji Korelasi spearman rank}

Program SPSS for windows version 25 digunakan untuk menentukan nilai korelasi dengan hasil sebagai berikut:

\section{Correlations}

\begin{tabular}{lllr|r} 
& & & \multicolumn{1}{c}{$\begin{array}{c}\text { Sistem } \\
\text { Informasi } \\
\text { Akuntansi } \\
\text { Persediaan }\end{array}$} & $\begin{array}{c}\text { Pengendali } \\
\text { an internal } \\
\text { persediaan }\end{array}$ \\
\hline Spearman's rho & $\begin{array}{l}\text { Sistem Informasi } \\
\text { Akuntansi Persediaan }\end{array}$ & $\begin{array}{l}\text { Correlation } \\
\text { Coefficient }\end{array}$ & 1.000 & $.904^{* *}$ \\
\cline { 3 - 6 } & Sig. (2-tailed) & .000 & .000 \\
\cline { 2 - 6 } & $\mathrm{N}$ & 25 & 25 \\
\hline
\end{tabular}




\begin{tabular}{l|l|r|r|r}
\hline \multirow{2}{*}{$\begin{array}{l}\text { Pengendalian internal } \\
\text { persediaan }\end{array}$} & $\begin{array}{l}\text { Correlation } \\
\text { Coefficient }\end{array}$ & $.904^{* *}$ & 1.000 \\
\cline { 2 - 5 } & Sig. (2-tailed) & .000 &. \\
\hline & $\mathrm{N}$ & 25 & 25 \\
\hline
\end{tabular}

**. Correlation is significant at the 0.01 level (2-tailed).

Gambar 4.8 Analisis Korelasi Spearman Rank

(Sumber: Data diolah menggunakan Ms. Excel 2010 dan software SPSS for windows version 25)

Hasil perhitungan menunjukkan nilai korelasi spearman rank antara variabel sistem informasi akuntansi persediaan (X) dan variabel pengendalian internal persediaan (Y) sebesar 0,904. Angka tersebut menunjukkan bahwa tingkat hubungan antara sistem informasi akuntansi $(\mathrm{X})$ terhadap pengendalian internal persediaan $(\mathrm{Y})$ memiliki tingkat hubungan yang sangat kuat karena berada diantara 0,80-1,000.

\section{Analisis Regresi Linear Sederhana}

Analisis regresi sederhana digunakan untuk mencari hubungan dari variable dependen. Pengolahan ini dilakukan dengan bantuan SPSS for windows version 25 sebagai berikut:

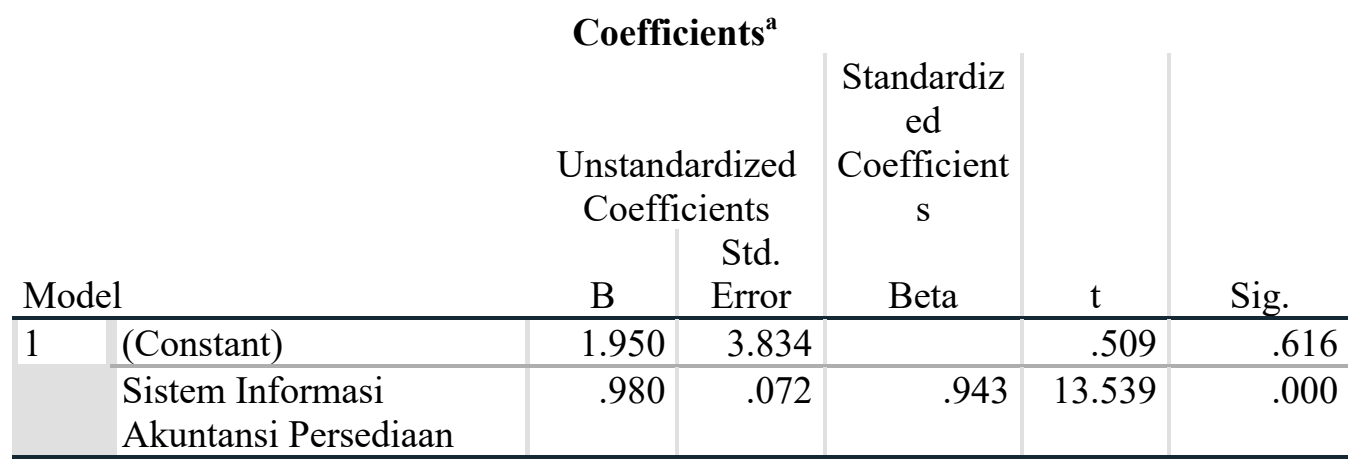

a. Dependent Variable: Pengendalian internal persediaan

Gambar 4.9 Analisis Regresi Linear Sederhana

(Sumber: Data diolah menggunakan Ms. Excel 2010 dan software SPSS for windows version 25)

Berdasarkan hasil pengolahan data, maka diketahui nilai konstansta (a) sebesar 1,950 dan nilai koefisien regresi (b) sebesar 0,980. Persamaan regresi linier sederhana menurut (Sugiono 2017) sebagai berikut:

$$
\mathrm{Y}=\mathrm{a}+\mathrm{Bx}
$$

Maka didapatkan persamaan regresi linier sederhana, yaitu:

Keterangan :

$$
\mathrm{Y}=1,950+0,980 \mathrm{X}
$$

$X$ : Sistem Informasi Akuntansi Persediaan

Y : Pengendalian Internal Persediaan

a : konstanta

$\mathrm{b}:$ koefisien regresi

Berdasarkan persamaan regresi linier sederhana diatas, dapat diambil kesimpulan:

a. jika variabel sistem informasi akuntansi persediaan $(\mathrm{X})=0$, maka nilai pengendalian internal persediaan (Y) adalah 1,950. 
b. jika nilai sistem informasi akuntansi persediaan $(X)$ bertambah 1 , maka nilai pengendalian internal persediaan (Y) akan bertambah 0,980 .

Koefisien regresi bernilai positif menunjukkan bahwa sistem informasi akuntansi persediaan $(\mathrm{X})$ berpengaruh positif terhadap pengendalian internal persediaan (Y). Artinya, semakin baik sistem informasi akuntansi persediaan maka semakin baik pula pengendalian internal persediaan.

\section{Analisis koefisien determinasi}

Koefisien determinasi dalam penelitian ini diolah menggunakan SPSS for windows version 25 dengan hasil sebagai berikut:

$$
\mathrm{Kd}=\mathrm{r}^{2} \times 100 \%
$$

\begin{tabular}{cc|c|c|c} 
& & \multicolumn{2}{c}{ Model Summary } \\
Model & R & R Square & $\begin{array}{c}\text { Adjusted R } \\
\text { Square }\end{array}$ & $\begin{array}{c}\text { Std. Error of } \\
\text { the Estimate }\end{array}$ \\
\hline 1 & $.943^{\mathrm{a}}$ & .889 & .884 & 1.391 \\
\hline
\end{tabular}

a. Predictors: (Constant), Sistem pengendalian internal persediaan

Gambar 4.10 Hasil Perhitungan Koefisien Determinasi

(Sumber: Data diolah menggunakan Ms. Excel 2010 dan ssoftware SPSS for windows version 25)

Dari hasil pengolahan data diperoleh angka yang terdapat pada kolom $\mathrm{R}$ Square sebesar 0,889 . Koefisien determinasi dapat dihitung menggunakan rumus:

$\mathrm{Kd}=0,889 \times 100 \%$

$=88,9 \%$

Hasil perhitungan koefisien determinasi $\left(\mathrm{r}^{2}\right)$ adalah sebesar $88,9 \%$. Hal tersebut menunjukkan bahwa pengaruh dari sitem informasi akuntansi persediaan (X) terhadap pengendaliaan internal persediaan (Y) adalah sebesar $88,9 \%$.

\section{Uji t (Pengujian Hipotesis)} berikut:

Pengujian hipotesis ini dilakukan dengan uji satu pihak dengan hipotesis sebagai

\section{Tabel 9 Hipotesis statistik}

\begin{tabular}{|l|l|c|}
\hline Ho $: \rho \leq 0$ & $\begin{array}{l}\text { Tidak terdapat pengaruh yang signifikan antara } \\
\text { sistem informasi akuntansi persediaan terhadap } \\
\text { pengendalian internal persediaan }\end{array}$ & \multirow{2}{*}{$\begin{array}{c}\text { Uji statistik } \\
\text { asosiatif satu pihak }\end{array}$} \\
\hline Ha $: \rho>0$ & $\begin{array}{l}\text { Terdapat pengaruh yang signifikan antara } \\
\text { sistem informasi akuntansi persediaan terhadap } \\
\text { pengendalian internal persediaan }\end{array}$ & \\
\hline
\end{tabular}

Pengujian hipotesis asosiatif satu pihak dalam penelitian ini diolah menggunakan SPSS for windows 25 dengan hasil:

\section{Coefficients $^{\mathrm{a}}$}




\begin{tabular}{|c|c|c|c|c|c|c|}
\hline & & $\begin{array}{l}\text { Unstan } \\
\text { Coeff }\end{array}$ & $\begin{array}{l}\text { rdized } \\
\text { ients }\end{array}$ & $\begin{array}{c}\text { Standardi } \\
\text { zed } \\
\text { Coefficie } \\
\text { nts }\end{array}$ & & \\
\hline & & & $\begin{array}{l}\text { Std. } \\
\text { Error }\end{array}$ & Beta & $\mathrm{T}$ & Sig. \\
\hline 1 & (Constant) & 1.950 & 3.834 & & .509 & .616 \\
\hline & $\begin{array}{l}\text { Sistem Informasi } \\
\text { Akuntansi } \\
\text { Persediaan }\end{array}$ & .980 & .072 & .943 & 13.539 & .000 \\
\hline
\end{tabular}

a. Dependent Variable: Pengendalian internal persediaan

Gambar 4.11 Hasil Perhitungan Pengujian Hipotesis

(Sumber: Data diolah menggunakan Ms. Excel 2010 dan software SPSS for windows version 25)

Hasil pengujian hipotesis adalah nilai uji t pada penelitian ini sebesar 13,539. Dengan derajat kebebasan sebesar 23 yaitu (n-2 atau 25-2) dan dengan pengujian satu pihak dan tingkat signitifikansi sebesar 5\%, maka nilai t tabel sebesar 1,714 diperoleh. Dengan demikian, $\mathrm{t}$ hitung $>\mathrm{t}$ tabel yaitu 13,539 $>1,699$ sedangkan nilai signitifikansi variabel sistem informasi akuntansi persediaan adalah sebesar $0,000<0,05$. Hal ini menunjukkan bahwa Ho ditolak dan Ha diterima. Berdasarkan hasil tersebut dapat diketahui bahwa terdapat pengaruh yang signifikan antara variabel sistem informasi akuntansi persediaan terhadap pengendalian internal persediaan di PT Trijati Primula.

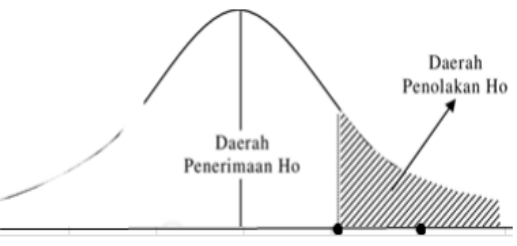

Gambar 4.12 Kurva $\quad \mathbf{t}_{\text {tabel }}=\mathbf{1 , 7 1 4} \mathbf{t}_{\text {hitung }=\mathbf{1 3 , 5 3 9}}$

Distribusi

Pihak Kanan

PEMBAHASAN

(Sumber :hasil pengolahan data, 2020)

\section{Sistem Informasi Akutansi Persediaan pada PT. Trijati Primula}

Terdapat tujuh indikator yang digunakan dalam variabel sistem informasi akuntansi persediaan, yaitu basis data, perangkat keras komputer, perangkat lunak komputer, jaringan komunikasi, dokumen dan laporan, prosedur, pengendalian. Berdasarkan dari jawaban responden, masing-masing indikator memperoleh skor yang termasuk kedalam kategori sangat tinggi. Variabel sistem informasi akuntansi memperoleh skor sebesar 1.589 yang termasuk dalam kategori sangat tinggi. Hal ini berarti pelaksanaan sistem informasi akuntansi persediaan di PT. Trijati Primula dalam pelaksanaannya sudah sangat baik.

Sistem informasi akuntansi dapat didefinisikan sebagai kumpulan (integrasi) dari sub-sub sistem/ komponen baik fisik maupun nonfisik yang saling berhubungan dan bekerja sama satu sama lain secara harmonis untuk mengolah data transaksi yang berkaitan dengan masalah keuangan menjadi informasi keuangan (Azhar Susanto 2013).

PT. Trijati Primula telah melaksanakan kegiatan bisnisnya dengan sangat baik sesuai dengan sistem informasi akuntansi persediaan yang ada perusahaan. Setiap 
orang yang menggunakan sistem sudah mengerjakan tugas yang diberikan sesuai dengan prosedur dan instruksi yang diberikan dengan baik. Hal tersebut dibuktikan dengan adanya kepastian bahwa data yang disimpan dalam sistem sudah benar dan sesuai dengan transaksi atau kegiatan yang terjadi, perangkat lunak atau aplikasi yang mudah digunakan, kelengkapan perangkat komputer yang memadai, sistem yang digunakan dapat mengawasi setiap kegiatan terkait persediaan, serta keamanan sistem dalam menyimpan data perusahaan.

Oleh sebab itu, setiap kegiatan terkait jual, beli dan perpindahan persediaan barang yang terjadi di PT. Trijati Primula sudah menerapkan sistem informasi akuntansi persediaan dengan sangat baik. Dengan demikian sistem informasi akuntansi di PT. Trijati Primula sudah berjalan dengan sangat baik.

\section{Pengendalian Internal Persediaan di PT. Trijati Primula}

Terdapat lima indikator yang digunakan dalam variabel pengendalian internal persediaan, yaitu lingkungan pengendali, kegiatan pengendali, pemahaman resiko, informasi dan komunikasi, dan pemantauan. Masing-masing indikator memperoleh skor sebesar 1.389 dan termasuk dalam kategori tinggi. Ini berarti pelaksanaan pengendalian internal persediaan di PT Trijati Primula sudah baik.

Pengendalian intern atas persediaan seharusnya di mulai pada saat barang di terima. Secara luas komponen pengendalian internal pada persediaan meliputi pengarahan arus dan penanganan barang mulai dari penerimaan, penyimpanan, sampai saat barangbarang yang siap untuk dijual (Herry 2014).

PT. Trijati Primula telah melaksanakan kegiatan pengendalian internal atas persediaan barang untuk melindungi aktiva perusahaan dengan baik. Masing-masing bagian atau divisi mempunyai tanggung jawab masing-masing dalam hal penerimaan barang sampai dengan barang tersebut terjual dan pemisahan tugas untuk kegiatan pencatatan dan penanganan fisik barang secara langsung sudah terlaksana dengan baik. Setiap dokumen yang terkait dengan jual dan beli barang sudah sesuai dengan ketentuan. Keamanan tempat menyimpan persediaan sudah terjamin. Selain itu, pencatatan yang dilakukan oleh staf atas barang yang keluar, masuk ataupun berpindah serta selalu dilakukan oleh staf taking atas persediaan barang setiap 3 bulan. Dengan demikian pengendalian internal di PT Trijati Primula sudah berjalan dengan baik.

\section{Pengaruh Sistem Informasi Akuntansi Persediaan Terhadap Pengendalian Internal Persediaan Pada PT Trijati Primula}

Berdasarkan hasil analisis dan pengujian hipotesis telah didapat bahwa hasil analisis korelasi spearman rank menunjukkan hasil koefisien korelasi sebesar 0,672 dimana hal tersebut memiliki arti jika hubungan antar sistem informasi akuntansi persediaan dengan pengendalian internal persediaan berada pada kategori kuat karena berada pada interval 0,60-0,799. Berdasarkan hasil analisis regresi linear sederhana yang dilakukan didapat bentuk persamaan regresi linear $\mathrm{Y}=5,575+0,157 \mathrm{X}$. Artinya, jika sistem informasi akuntansi persediaan mengalami kenaikan 1, maka pengendalian internal persediaan akan mengalami kenaikan sebesar 0,157 . Karena koefisien bernilai positif maka terjadi hubungan positif dan artinya terjadi kenaikan terhadap system informasi akuntansi persediaan (X) maka mengakibatkan pengendalian internal persediaan (Y).

Berdasarkan hasil analisis koefisien determinasi, kontribusi variabel sistem informasi akuntansi persediaan $(\mathrm{X})$ terhadap variabel pengendalian internal persediaan (Y) sebesar $r^{2} \times 100 \%$ maka diperoleh $r^{2}$ sebesar 0,889 atau $88,9 \%$. Hal ini menunjukkan bahwa presentasi pengaruh sistem informasi akuntansi persediaan terhadap pengendalian internal persediaan adalah sebesar $88,9 \%$. 
Berdasarkan uji $\mathrm{t}$ diperoleh nilai $\mathrm{t}_{\text {hitung }} 1,844$ dengan signitifikansi $(\alpha)=5 \%$ dan derajat kebebasan $(\mathrm{dk})=25$ didapat nilai $\mathrm{t}$ tabel sebesar 1,699. Dapat dilihat jika $\mathrm{t}_{\text {hitung }}$ $1.844>\mathrm{t}_{\text {tabel }} 1,699$ sedangkan nilai signifikansi adalah sebesar $0,000<0,05$ maka $\mathrm{H}_{\mathrm{o}}$ ditolak dan $\mathrm{H}_{\mathrm{a}}$ diterima. Hal ini menunjukkan informasi akuntansi persediaan berpengaruh signitifikan terhadap pengendalian internal persediaan pada PT Trijati Primula.

Penelitian ini diperkuat oleh penelitian sebelumnya yang dilakukan oleh Djajun Djuhara (2014) dengan judul pengaruh sistem informasi akuntansi persediaan terhadap pengendalian internal persediaan pada CV Tri Multi Manunggal Bandung. Hasil dari penelitian ini menunjukkan bahwa terdapat pengaruh positif antara sistem informasi akuntansi persediaan barang terhadap pengendalian internal persediaan barang pada $\mathrm{CV}$ Tri Multi Manunggal Bandung. sebesar 75,70\%.

Pengendalian internal merupakan bagian dari sistem informasi akuntansi (Romney dan Steinbart 2015). Maka semakin baik penerapan sistem informasi akuntansi persediaan maka semakin baik pula pengendalian internal yang dihasilkan. Pengendalian sangat diperlukan untuk mengawasi jalannya aktivitas perusahaan. Hal ini dimaksudkan untuk menghindari terjadinya hal-hal yang dapat menimbulkan kerugian perusahaan seperti penyelewengan, kecurangan, pemborosan, dan pencurian baik dari pihak dalam maupun pihak luar perusahaan dalam menilai perusahaan serta untuk mengevalusi dan mengambil tindakan perbaikan dalam mengantisipasi kelemahan perusahaan.

\section{KESIMPULAN}

\section{Kesimpulan}

Berdasarkan hasil penelitian dan pembahasan mengenai pengaruh sistem informasi akuntasi persediaan terhadap pengendalian internal persedian pada PT.Trijati Primula dapat diambil kesimpulan sebagai berikut:

1. Sistem informasi akuntansi persediaan yang ada pada PT. Trijati Primula dilihat dari sudut pandang pelaksanaannya dianggap sudah baik dimana sistem informasi akuntasi persediaan telah di dukung dengan indikator-indikator yang saling berhubungan sehingga dapat menghasilkan sistem yang mampu membantu karyawan menyelesaikan pekerjaannya dengan baik.

2. Pengendalian internal persediaan yang ada pada PT. Trijati Primula sudah berjalan dengan baik sesuai dengan SOP yang berlaku.

3. Terdapat pengaruh yang sinifkan antara sistem informasi akuntasi persediaan dan pengendalian internal persediaan pada PT. Trijati Primula . Hal ini menunjukan semakin baik sebuah sistem informasi akutansi persediaan yang diterapkan dalam sebuah perusahaan maka akan semakin baik pula pengendalian internal persediaan yang dihasilkan dalam sebuah perusahaan.

\section{DAFTAR PUSTAKA}

B. Rommy, Paul John Steinbart. 2016. Sistem Informasi Akuntansi. Jakarta: salemba empat.

Djuhara, Djajun. 2014. "Pengaruh System Informasi Akuntansi Persediaan Terhadap Transparan Pengendalian Intern Persediaan Pada CV. Tri Multi Manunggal Bandung." Jurnal Akuntansi.

Hery. 2014. Pengendalian Akuntansi Dan Manajemen. Jakarta: Kencana.

Meita Sekar Sari, Dkk. 2019. "Pengaruh Pengendalian Internal Persediaan Dan Kualitas Sistem Informasi Akuntansi Terhadap Pencegahan Kecurangan (Fraud) Persediaan Pada PT. Indofarma Global Medica Bandar Lampung." Jurnal Akuntansi.

Mugiarti, Dkk. 2016. "Pengaruh Sistem Informasi Akuntansi Persediaan Barang Terhadap Pengendalian Intern Persediaan Barang Pada Toko Besi Dan Bangunan Serbaguna Di Ajibarang." Jurnal Akuntansi. 
Mulyadi. 2016. Sistem Akuntansi. Jakarta: salemba empat.

Sigit Hermawan, Dkk. 2019. Akuntansi Perusahaan Jasa,Dagang, Dan Manufaktur. Sidoarjo: Indomedia Pustaka.

Sugiyono. 2019. Statistika Untuk Penelitian. Bandung: Alfabeta, CV.

Susanto, Azhar. 2013. Sistem Informasi Akuntansi. Bandung: Lingga Jaya. 